\title{
STUDENTS' RESPONSE TO READING WHILE LISTENING GRADED STORIES ACTIVITIES
}

\author{
Nguyen Thi Hue*, Mai Thi Thanh Thu, \\ Pham Thi Hoang Ngan, Vu Thi Thu Phuong \\ Nam Dinh University of Nursing
}

\section{ABSTRACT}

Recent research on listening while reading activities mostly focus on its effectiveness or comparison with other activities or adopt quantitative measures. The purpose of this qualitative action research is to investigate how and why first year students at Nam Dinh University of Nursing respond to reading while listening graded stories in English class. In this study, in order to triangulate the data, three data collection methods were used; namely, individual interview, group interview, and observation. The participants were 15 first year students with varied English proficiency levels from elementary to pre-intermediate. Data were thematically analyzed. After 14 weeks of implementing the activities, participants positively reported on their engagement in the class and benefits of the activities on language development; however, there were also problems with stories selection and follow up activities.

Key words: foreign language teaching methods; listening while reading; graded stories; qualitative action research; Nam Dinh University of Nursing

Received: 15/5/2019; Revised: 14/6/2019; Approved: 16/6/2019

\section{PHẢN HỒI CỦA SINH VIÊN VỀ PHƯƠNG PHÁP ĐỌC VÀ NGHE SONG SONG GRADED STORIES}

\author{
Nguyễn Thị Huế*, Mai Thị Thanh Thu, \\ Phạm Thị Hoàng Ngân, Vũ Thị Thu Phương \\ Trường Đại học Điều duõ̃ng Nam Định
}

\section{TÓM TẮT}

Hầu hết các nghiên cứu gần đây về phương pháp Đọc và nghe song song (Reading while listening) chỉ tập trung vào hiệu quả của phương pháp này hoặc so sánh với các phương pháp khác hay sử dụng phương pháp nghiên cứu định lượng. Mục đích của nghiên cứu hành động định tính này nhằm trả lời câu hỏi sinh viên năm thứ nhất tại trường Đại học Điều dưỡng Nam Định phản hồi như thế nào và tại sao khi áp dụng kỹ thuật đọc và nghe song song các câu truyện ngắn được đơn giản hóa trong lớp học tiếng Anh. Để thu thập và đối chiếu thông tin, nhóm nghiên cứu đã sử dụng 3 phương pháp thu thập dữ liệu gồm: phỏng vấn nhóm, phỏng vấn cá nhân và quan sát. Đối tượng nghiên cứu là 15 sinh viên năm nhất tại Đại học Điều dưỡng Nam Định với trình độ khác nhau từ sơ cấp tới tiền trung cấp. Dữ liệu được phân tích theo chủ đề (thematically analysis). Sau 14 tuần áp dụng phương pháp này, sinh viên phản hồi tích cực về mức độ tham gia vào các hoạt động và lợi ích của các hoạt động nói trên với sự phát triển ngôn ngữ; tuy nhiên, vẫn còn một số vấn đề liên quan đến các hoạt động bổ trợ và việc lựa chọn các câu truyện.

Từ khóa: phuong pháp giảng dạy ngoại ngũu; đọc và nghe song song; graded stories; nghiên cứu hành động định tính; Đại học Điều duõng Nam Định

Ngày nhận bài: 15/5/2019; Ngày hoàn thiện: 14/6/2019; Ngày duyệt đăng: 16/6/2019

* Corresponding author. Email: nguyenhue.ndun@gmail.com

DOI: https://doi.org/10.34238/tnu-jst.2019.06.1438 


\section{Introduction}

At Nam Dinh University of Nursing (NDUN), English is compulsory with 18 credits conducted in three semesters. The students come from different English learning background, and their English competence is considerably different varied from elementary to pre-intermediate. The students are so unique in that becoming a student nurse is not their first choice, most of them desire to study in medical university but their exam grades were not good enough. This is their first semester in a nursing school, some of them are still not very happy with this new learning environment.

On top of that, English classes are four-hour long session, which challenges both students and teachers' concentration. Typically, attending night shift is a task of a student nurse, who then rushes to my class and keep yawning the whole lesson. According to Krashen's Affective filter hypothesis, a learner will not absorb knowledge completely if he/ she is in bad physical and emotional condition such as depressed, worried, fidget or drowsy. Accordingly, in order to ensure optimal learning environment, teachers should create a low pressure and supportive class atmosphere for their learners [1].

In short, constrain curriculum and learning schedule, crowded and mix-ability class, all contribute to students' lack of motivation and engagement in the lesson, which inhibit the language learning process. In order to engage students in learning activities, the study was conducted to introduce reading while listening graded stories to English class.

\section{Literature review}

Reading while listening is not a new strategy but an old idea reworked. It has been used for native speakers at elementary schools and students with reading disability decades ago. Reading while listening short stories belongs to extensive reading, which has long been used in language teaching. There are numerous studies that confirm the effectiveness of extensive reading in general English proficiency, writing [2], [3], [4], [5], [6]; in reading and vocabulary [7], [8], [9]; grammar [10], and attitudes toward reading [3].

Researchers have long proved the benefits of reading while listening in helping listening comprehension and improvement [11], [12], [13], and vocabulary acquisition [14]. In his study, Vandergrift [14] found that reading while listening helps to create the auralwritten verification stage, which is helpful for both low and high proficiency students in recognizing words. Goble [15] concluded that the more students do reading while listening the higher TOEFL score they get. However, in his study, reading while listening was an out of class activity, which he admitted that it was difficult to control if student apply it properly. In this study, reading while listening is an in-class activity with the control and guidance of the teacher to ensure the proper procedure. Overall, the above studies were conducted in a certain period of time and use the test score to evaluate the effectiveness of reading while listening method. However, Chang [13] suggested that it is better to employ reading while listening to develop students' listening long-term ability rather than just to increase their short-term scores.

Also, Chang [13] found out that the majority of the students agreed that "reading while listening made listening tasks easier, the duration seem shorter, the stories more interesting, and they paid much better attention" (p.660). Students will be motivated to practice more regularly out side the class as an entertainment. Consequently, their incidental learning will happen, their language ability will be improved.

Overall, the above studies were conducted in a certain period of time (at least a semester) and use stories that include several chapters, students have to wait several sessions to know the ending. In this short stories of about five minutes each were used. Since short stories usually have a beginning, middle and an end, they encourage students at all levels of language proficiency to keep reading them until the end to see what happened finally. 


\section{Methodology}

The study was designed to answer the research question: "How and why do $1^{\text {st }}$ year students at Nam Dinh university of Nursing respond to reading while listening graded short stories in English class?"

\subsection{Qualitative action research}

Through this study, the author aimed at investigating students' opinion, attitudes, and behaviors in her class using graded readers with audio along. This kind of information can be best achieved by qualitative data collection methods since the study did not intend to test any hypothesis or assumption. Instead, it was aiming to see what was actually happening in the classroom. In addition, the author was not trying to control variables because in my opinion, studying a learning strategy need a natural and holistic approach taking into account all factors contributing to the learning process. By conducting this research, the researchers "seek to understand phenomena in contextspecific settings" without any attempts to generalize finding, predict trend, or determine a causal relationship between variables [16], thus quantitative research is not feasible.

As a practitioner, it is valuable to conduct classroom action research for the following reasons. Firstly, to some extent, there is still a gap between academic research and reality in the classroom [17]. With classroom research, teachers are in the position to discover their own problems in their own settings and try out their own solutions instead of blindly following teaching methods recommended by the latest study. Secondly, classroom research is helpful for teacher's professional development because it involves a process of research, reflect and change, which provides a closer look at the teacher's own practice in a systematic way. Further more, teachers have chances to step back and ask questions about what was happening, why and what to do next. Since classroom research pays special attention to students, teacher can explore the effects of their teaching on the students, how to cooperate with other teachers, or how to influence others to transform the whole institution [17]. Moreover, through the process of conducting small research, the teacher understands more about the classroom as a learning environment therefore he/ she can give appropriate decision on classroom teaching methods.

Another reasons for action research is that it is a cyclic process and after each cycle teachers will reflect on what they have done, what went wrong and modification for the next cycle or the next class.

\subsection{Research methods}

In this study, in order to triangulate the data, three data collection methods were used, namely: individual interview, group interview, and observation. For the purpose of triangulating data, the researcher combines data from various sources and at different times, in different places or from different people. During the analysis of data, I always borne in mind to compare and contrast within and between data set to triangulate the data as well as to find patterns.

\section{Observation}

Observation allow researchers to know more about people in real-world situation rather than asking them questions in an interview or looking at their answer in a questionnaire [18]. I conducted three focus observations at three different occasions at the second session, the $5^{\text {th }}$ session and the final session with a view to gathering as thick description as possible to see changes in students' perception of reading while listening graded stories.

\section{Group interview and individual interview}

Both interviews give me information about students' opinion and attitude toward the innovation. I used semi-structured interviews, which use a list of question prepared before hand as an interview schedule. I interviewed a group of five students and 10 individual students who gave me the consent. The interviews took place in our daily classroom in order to ensure comfortable atmosphere and to minimize the power gap so that students would feel free to express their views. 


\subsection{Participants}

Fifteen students participated in the study, 10 of whom were girls and the other five were boys aged from 18-20. The students come from different English learning background, but most of them have at least eight years of learning English at secondary and high school. Hence, their English competence is considerably different varied from elementary to preintermediate. Especially, there are students whose English is still frozen after one or two years concentrating totally on the university entrance exams, which excluded English.

\subsection{Procedure}

The study took place in 14 weeks. The first two weeks was for selecting stories and administrative document including permission from NDUN, orientation session, delivering and collecting consent form. Regarding selection of stories, there are some concerns. In order to maintain students' interest, the stories should be at appropriate level with at least $95 \%$ known words to ensure students' comprehension and pleasure reading [19]. The last two weeks is for collecting and analyzing data. The reading while listening will start at week 3 and finish at week 12 with 20 sessions, each will last from 25-30 minutes. It is an in-class activity. The session will start with a warm-up activity that briefly introduces the theme and context of the stories. This introduction give students the story's background information which will help them to understand and engage with it. Students then read the story for 5 to 10 minutes with the audio file along. Then, students will work in groups to discuss and check their understanding of the story. Then come the follow up activities varying from retelling the story in their own words, inventing another ending, discussing the differences between the book and the movie (if available) or enacting a scene from the story. There was a principle for the follow up activities that they are not a kind of exercise or assessment and let students enjoy reading without worrying about the evaluation.
The interviews took place in the final week with one group interview and 10 individual interviews. The interviews were conducted at their daily classroom so that students felt familiar and safe. Pseudonyms from S1 to S15 were used in all sets of data with the view to maintain students' confidentiality. Some times, informal interviews were conducted to clarify students' behaviors during observation. This type of interview gave thick descriptions of occurrences since the memory was still fresh.

The analysis of data began as soon as the data was collected. The data was analyzed thematically. While searching the data, the author looked for the common themes and patterns among observation, group and individual interview responses which recurred and became emergent categories. When analyzing data, similar response were highlighted with the same colors, emergent themes were identified and labeled. For the observation, I study the observation notes to look for common themes and patterns. The observation were divided into two chunks namely the reading while listening part and the follow up activities. On -task and off-task behaviors as well as students' emotional behaviors were three categories. On-task behaviors included finger pointing or looking at the screen, writing down, paying attention to friends' performance, participating ingroup activities and asking and/or answering question. Off-task behaviors included looking to other places, playing with objects, laying heads on desks, fidgeting, talking to friends. Emotional behaviors were verbal languages, facial expressions and body languages such as smiling, nodding, head shaking, yawning, frowning, and pouting. During the process of analyzing data, the author worked with each set of the data separately and across the data to ensure triangulation to occur. Students' responses in the interview were compared with their behaviors during the observation. Then axial coding was used to seek patterns on each data set as well as across data sets. 
During this process, I will keep asking myself questions suggested by Dahlberg \& McCaig [20]: "Are there any dominant theme that exist across all the data? Can you identify any connections between your categories? How does what you have found compare to what had already been written in the literature?" (p.156).

\section{Results}

\section{Theme 1: Students' engagement}

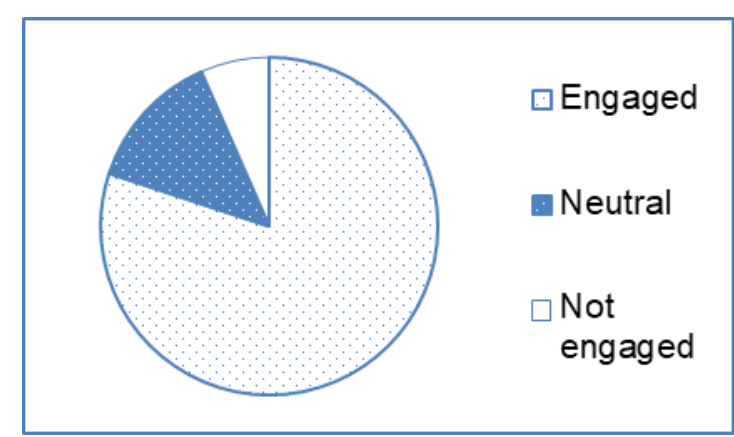

Figure 1. Students' engagement

The data from my interviews and observations were consistent on this issue. $80 \%$ of the students showed preference to listening while reading activity. S3, S4, S8, S11 agreed that the stories were interesting and easy to understand. In the focus group, S11 explained that she was attracted to the story because "the language was not too complicated... I could concentrate more when followed the listening." This was totally new activities for all the students. S15 stressed that "I like it. It sounded like the karaoke, the story karaoke... I can feel the melody" (the narrative sound). However, the observation notes showed that S15 often close her eyes or looked outside during the stories. I can infer that she was focusing on the "melody" of the story and preventing herself from distracting text. "It was good to see and listen to the word at the same time" said S10. I often introduced the activity at the beginning of third period when students' energy came down. S1 admit that "no drowsy at all". Normally, at that time of the day, there were students who put their head on their desk. However, in my observation, S1 still yawned several times. He yawned and sighed the most in the class. In the informal interview after the class, he explained that he was so tired because of the night shift that week. S3, a proficient girl, showed some off-task behaviors like playing with the pen or preparing her hair in the class. In the interview, she said, "the stories I know before so they are not as interesting as the new one. With the story I do not know, I have to keep concentration to follow the plot. It is more challenging and interesting". In contrast, after the class one day, some students asked me informally to select famous stories like "the little red riding hood" for the next session because with the familiar plot, they can learn how to express in English. During my observation, it was noticeable that their face lit up with smile and hand gesture when I declared "story time." This confirmed their strong interest in the innovation, which is in line with Chang [13] and Brown \& Donkeabua [14].

\section{Theme 2: Reading while listening helped students in language learning}

This theme focused on the benefits brought in by the innovation. $73.3 \%$ of students agreed that the activities help improve at least one language aspect or skill development. Pronunciation, vocabulary and listening skill were the most prominent with $10,8,7$ students referred to respectively.

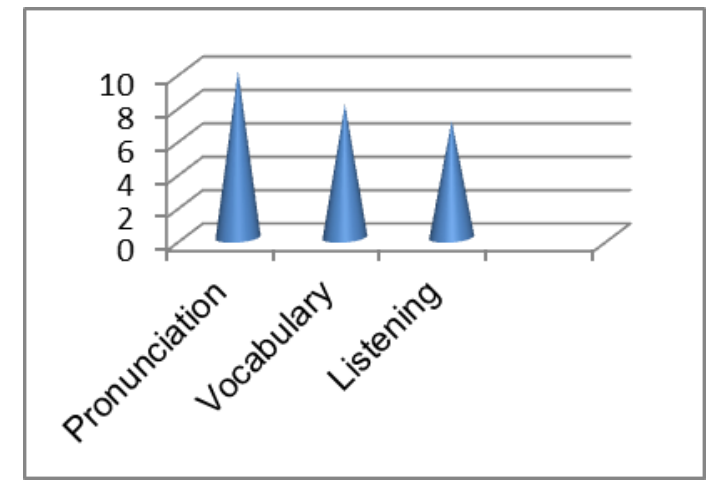

Figure 2. Language improvement

In the observation, I specially paid attention to S6, a boy sitting in the front row. In the first observation, he often raise his eyebrows with surprising face, sometimes he shook his head and smiled then wrote down something. 
In final sessions, he did less. I inferred that he might be surprised by the story; however, in the interview he revealed it was the pronunciation that caught his attention because he realized that he mispronounced some very common words. Similarly, S13 reported that "I find it interesting with the connected speech where in the text I can separate words but in the audio, I can not detect word boundary. But later on, things go better." The focus group also listed pronunciation as the most advantages of reading while listening. This is in line with responses of students from Chang [13]. Another feature that came out from the data was the consolidation of previous grammar and structures. S12 told me "it is easier for me to remember grammar rules or sentence structure when I saw them and hear them in the story context". Additionally, the innovation also helped improve students' confidence and motivated them to read more. They feel more confident to say some full sentences now because they listened to them and know how to speak naturally. In the group interview, students said that they used to think they were not able to read stories in English since there were numerous new words. With the graded stories in which interesting scenario is presented by simplified language, it is much easier and they are eager to read more. S8 said: "Being exposed to this kind of activity make me love English, which I used to think of as a nightmare. I have never read so many English stories before and I will continue to read more".

However, no one referred to accidental vocabulary acquisition like in Chang [13], Brown and Donkeabua [14]. It can be explained that, accidental vocabulary acquisition only occurs when the word recurs often enough with more sessions.

\section{Theme 3: Problems with follow up activities}

The data from my observation showed that things totally went wrong with follow up activities. $33.3 \%$ of the students find it difficult to fulfill the follow - up tasks. When it came to the story summary activities, the groups often send the same person to the board. Also, this was that person who worked the hardest. I also noticed that there was noncontribute participant who did nothing. Moreover, different groups acted differently while fulfilling the task. The group with better students often finished earlier then gossiped while the weaker one often asked for more time. In the interview with a group leader, she expressed her dissatisfaction when she "had to do most of the work". As for the summary task, students did not really work even when the teacher set the time limit. During the task time, students seemed to be distracted. Some looked at friends' paper, some looked outside, some yawned and put their head on their hand. Finally, they asked me to set it homework. The next day, they handed in nearly the same copy. For the role play, there were still uneven parts between group members. Often, the best one would always be the one who acted the most while the weak one even said nothing or just performed some body languages. The role play had variety of complaints from students. S9, S4, S8 and S11 agreed that "it is really difficult to create a play from such short stories within 10 or 15 minutes". As I observed, S4 and S11 were less active participants who often gossiped or teased others. The group interviewees suggested that "the follow up activities should be assigned as homework and performed on the next lesson, that way we have more time to prepare". Furthermore, time allocation was another source of problem. According to data from the interviews, the follow up activities were time-consuming; however, the primary problem might be inefficient group work, in which students did not know how to interact, cooperate and allot work for each member.

\section{Discussion}

The first point to take into consideration would be students' engagement. It is understandable because this is the first time 
reading while listening has been introduced in my class, so students might welcome it as a novelty effect. Though most of the students were engaged in the reading while listening activity, the taste varied among groups of students. The competent ones preferred the unfamiliar stories for more challenges whereas the weaker ones favored the common ones. Boys insisted that the stories were too childish; they preferred thrilling ones.

Moreover, this mode also gave students autonomy, which means they can manage their own learning preferences. They can decide to listen to the audio only until they hear incomprehensible utterances and then consult the text or reading while listening. Normally, at the very first sessions, students follow both the text and the audio, then afterward they could just ignored the text. S2 even created her own way to employ the method. She said, "When I get used to the mode, I challenge myself by listening to the audio and wrote down the story like a dictation exercise."

\subsection{Benefits of reading while listening}

Obviously, data from different sources confirmed that reading while listening brought in positive results. Word pronunciation gains were stressed by group of weaker students, who mainly come from rural and suburban areas where students have less chance to expose to authentic English. Stronger students reported that they were more confident with sentence intonation and vocabulary consolidation. It is easy to understand that more competent students already master the pronunciation so it does not bother them and their brain automatically shift the attention to other aspects like vocabulary. Actually, there are not many new lexical items in the graded stories, thus, "new vocabulary" may mean the passive vocabulary, which students rarely use but they already know.

Actually, my class is a mixed ability class where students' language proficiency varies deeply. Therefore, it seems impossible for a certain story to be suitable for all students.
Also, the weak students said that the stories become easier to understand when being read. This feature was also reflected by students in [13]. She explained that learners of foreign language tend to read word by word. As a result, sentence integrity is broken down making it difficult to understand. With reading while listening mode, the text is presented in larger semantic unit, which in turn leads to better comprehension. In general, in terms of benefits for students, the innovation was a success to some extend.

\subsection{Unsuccessful follow up activities}

It is obvious from the data that insufficient teamwork skills are fundamental reason for the failure. Most of the tasks are in the form of group work with the primary aim to foster cooperation between students. Initially, I supposed that group work would help me save time because "three heads are better than one". But in fact, inefficient group work waste the class time. At high schools in Vietnam, especially in rural and remote areas, where teaching methods often focus on test oriented, students had little chance to develop teamwork ability thus led to students' lack of such basic skills. Furthermore, the students were in their first year at a completely new learning environment, they preferred to work with their close friends instead of the ones they were not so acquainted. Actually, during the project, I kept the same groups (I group students sitting next to one another) due to the crowded class and small classroom, it was inconvenience for students to move around to form new groups. This created chance for passive group member as they became more dependent in groups with dominant member. At the beginning of the study, I did not think of these situations, I expected that students would be involved in the group work activities because I assumed that they at least had some experience working in a team. For the next cycle, I will deliver a test to clarify students reading ability and vocabulary size so that I will be able to select more appropriate level of graded stories. I will also spend some time training students on group 
work skills. Moreover, during the implementation of the project, I will take into consideration various grouping methods for more effective application.

\section{Conclusion}

This paper described the experiences and responses of first year nursing students at Nam Dinh University of Nursing to reading while listening activities in English class. In summary, reading while listening activities have positive effects on student's engagement and student's language learning process. Though students' competency varied, the activities benefited students differently. The data presented here have contributed to the teaching professional development of the author and hopefully, it is helpful for other colleagues.

\section{REFERENCES}

[1]. P. L. Lightbown, and N. Spada, How languages are learned, (3rd ed.), Oxford University Press, Oxford, 2006.

[2]. Mason, B., \& Krashen, S., "Extensive reading in English as a foreign language", System, vol. 25, 91-102. DOI: 10.1016/S0346251X(96)00063-2, 1997.

[3]. Lee, S. Y., "Facilitating and inhibiting factors of EFL writing: A model testing with SEM". Language Learning, vol. 55, 335-374. DOI: 10.1111/j.0023-8333.2005.00306.x, 2005.

[4]. Lee, S. Y., \& Hsu, Y., "Determining the crucial characteristics of extensive reading programmes: The impact of extensive reading of EFL writing", The International Journal of Foreign Language Teaching, Summer, 12-20, 2009.

[5]. Kirin, W., "Effects of extensive reading on students' writing ability in an EFL class", The Journal of Asian TEFL, vol 7, 285-308, 2010.

[6]. Mermelstein, A. D, "Improving EFL learners' writing through enhanced extensive reading". Reading in a Foreign Language, vol. 27, 182198, 2015.
[7]. Bell, T., "Extensive reading: speed and comprehension", The Reading Matrix, vol. 1(1), 19-23, 2001.

[8]. Lee, S. Y., "Revelations from Three Consecutive Studies on Extensive Reading", Regional Language Center (RELC) Journal, vol. 38 (2), 150-170, 2007.

[9]. Sheu, P.H., "The Effect of Extensive Reading on Learners' Reading Ability Development". Journal of National Taipei Teachers College, vol. 17(2), 213-228, 2004.

[11]. Lee, S. Y., "Revelations from Three Consecutive Studies on Extensive Reading". Regional Language Center (RELC) Journal, vol. 38 (2), 150-170, 2007.

[12]. Vandergrift, L., "Recent developments in second and foreign language listening comprehension research", Language Teaching, vol. 40, 191-210, 2007.

[13]. Chang, C.-S. "Gains to L2 listeners from reading while listening vs. listening only in comprehending short stories", System, vol. 37, 652-663, 2009.

[14]. Brown, R., Waring, R., Donkaewbua, S., "Incidental vocabulary acquisition from reading, reading-while-listening, and listening to stories", Reading in a Foreign Language, vol. 20, 136-163, 2008.

[15]. Gobel, P., "The effect of reading while listening on TOFL gain", English Forum of Higher Education, vol. 1, 45-51, 2011.

[16]. Mckay, L., S., Researching second language classrooms, Taylor and Francis, New Jersy, 2006.

[17]. Ferrance, E., Action research, LAB, Brown University, 2000.

[18]. Burns, A., Doing action research in English language teaching. A guide for practitioners. Routledge, London, 2009.

[19]. Day, R. \& Bamford, J., Extensive Reading In The Second Language Classroom. Cambridge University Press, Cambridge, 1998.

[20]. Dahlberg, L. \& McCaig, C. (Eds). Practical Research and Evaluation: A Start-to-Finish Guide for Practitioners. Sage publication, London, 2010. 